\title{
Self-Efficacy and Outcome Expectancy: Analysis of Theory and Measurement in Occupational Therapy
}

\author{
Kayoko TAKAHASHI, MS, OT ${ }^{1}$
}

ScD Candidate in Doctoral Program in Rehabilitation Sciences, Sargent College of Health and Rehabilitation Sciences, Boston University

\begin{abstract}
Occupational therapy seeks to effectively change clients' behavior to result in better quality of life by both focusing on tasks that clients find purposeful and meaningful and by enhancing clients' sense of competence. Self-regulatory system theory similarly demonstrates that behaviors are best predicted by the combined influence of one's competence to perform a task (self-efficacy) and the purposefulness and meaningfulness of a task (outcome expectancy). In this paper, twenty-four scales for self-efficacy and outcome expectancy for older adults were reviewed. However, these scales were found not to be validly following the theoretical framework. Furthermore, in clinical contexts, therapists rarely evaluate clients' states using scales; rather they observe clients' nonverbal and verbal behavior. This observational assessment is not only found to be reliable but also helps to develop a strong working alliance and better rehabilitation outcome. Research is currently underway to develop a systematic method to identify which of the clients' cues are valid and reliable expressions of self-efficacy and outcome expectancy.
\end{abstract}

Key words: measurement, outcome expectancy, self-efficacy, self-regulatory system, theory

(Asian J Occup Ther 6: 23-34, 2007)

\section{Introduction}

Occupational therapists focus on tasks that their clients find personally purposeful and meaningful and for which the clients have positive

Received: August 24, 2007, Accepted: October 30, 2007 Corresponding to: Kayoko Takahashi, ScD Candidate in Doctoral Program in Rehabilitation Sciences, Sargent College of Health and Rehabilitation Sciences, Boston University, 635 Commonwealth Ave. \# 553 Boston, MA 02215 U.S.A.

Phone: 1-617-627-4591 fax: 1-617-627-4824

e-mail: kayo@bu.edu expectations related to potential outcomes of the tasks. The philosophical assumptions that drive rehabilitation practice include the link between task performance and sense of competence (Gage \& Polatajko, 1994): Successful completion of a task that a person finds purposeful and meaningful can lead to an increase in the person's sense of competence and in the person's willingness to engage in other tasks. Research in occupational therapy has been done to support this philosophical assumption (Bakshi, Bhambhani, \& Madill, 1991; Dickerson \& Fisher, 1997; Ferguson \& Trombly, 1997; Kircher, 1984; Miller \& 
Nelson, 1987; Morton, Barnett, \& Hale, 1992; Murphy, Trombly, Tickle-Degnen, \& Jacobs, 1999; Riccio, Nelson, \& Bush, 1990; Takahashi, 2002; Thibodeaux \& Ludwig, 1988; Trombly, 1993, 1995, 2002; Yoder, Nelson, \& Smith, 1989).

In order to facilitate task performance, occupational therapists not only choose a task that clients find purposeful and meaningful, but also set a goal to increase the client's sense of competence (Christiansen, 1991; McAuly, 1993; Trombly, 1993). Enhancing the client's sense of competence has been an important focus of occupational therapy from its early days. Adolph Meyer (1922), a founder of occupational therapy, described the value of feeling the satisfaction and achievement that is associated with successful completion of a project. Robert White (1971), a scholar of motivation and human behavior, stressed that occupational therapists need to be aware of a client's sense of competence. By both focusing on the task that clients find purposeful and meaningful and enhancing the client's sense of competence, occupational therapy seeks to effectively change a client's behavior to result in a better quality of life.

However, occupational therapy does not have a specific theoretical framework to support this philosophical assumption. Putting clinical phenomena into a theoretical framework helps practice in two ways. First, it helps in a retrospective way, to systematically understand the condition of a client. Second, it helps in a prospective way, to systematically guide effective treatment planning for the client. One theoretical framework that is highly consistent with occupational therapy practice is the self-regulatory system model (Bandura, 1977, 1986, 1991, 1997) demonstrating the conditional relationship between cognition and behavior involved in human actions.

Moreover, only a few measurement tools used in healthcare fields precisely follow a theoretical framework. Having a measure is not only the first step for a therapist to understand client's condition, but also to see the outcome of the intervention so that a therapist can provide a better and more effective intervention for each client.
The purpose of this paper is first to analyze one of the theories by Bandura about people's behavioral change via a self-regulatory system, with a specific focus on measurements derived from the theory that have been used in rehabilitation research with older adults. A discussion will then go further into a clinical application of how occupational therapists can assess the theorized factors to better understand behavioral change.

\section{The Self-regulatory System as a Theoretical Framework}

According to Bandura's framework, human action is a self-regulatory system, in which selfregulation is defined as self-directed change influenced by the environment. Bandura (1977, 1986, 1991, 1995, 1997) states that behavior and self-regulation processes are best predicted by the combined influence of one's belief in the ability to perform a task (self-efficacy) and the results one anticipates from having performed these tasks (outcome expectancy). Both self-efficacy and outcome expectancy are part of the cognitive process prior to one's action, because self-efficacy is a perception of oneself capably performing a behavior and outcome expectancy is a perception of the purposefulness and meaningfulness of doing that behavior. These two types of cognitive perception then influence the person's actual behavior of doing a task. Self-efficacy influences the choices people make, their aspirations, how much effort they put into achieving the task, and how long they persevere in the face of difficulties (Bandura \& Adams, 1977). Outcome expectancy influences the amount of effort they put into achieving the task, but also influences the amount of satisfaction they feel in achieving the task and eagerness to move on to a similar or more difficult task.

To apply Bandura's framework, Fig. 1 presents an example of an occupational therapy client and how self-efficacy and outcome expectancy enter into her own motivation to do a task. Mrs. Sato is a 67-year-old homemaker with Parkinson's disease. She lived with her 45-yearold daughter who was a busy lawyer, and three 


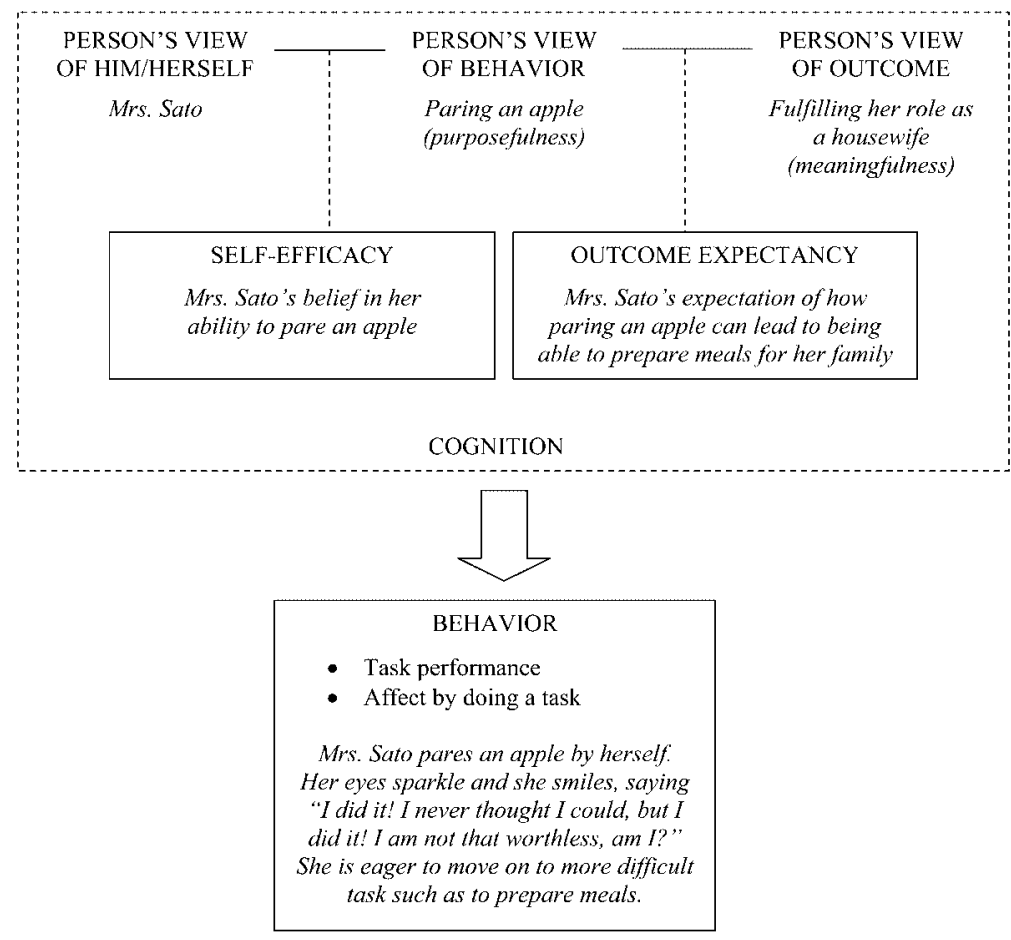

Adapted from Self-efficacy: The exercise of control (p. 22), by A. Bandura, 1997, New York: W.H. Freeman and Company.

Fig. 1. Self-regulatory system. The conditional relationship of self-efficacy and outcome expectancy to an actual behavior

grandchildren (10-year-old girl, 14-year-old boy, and 17-year-old boy). She was in charge of the entire household and cares for the grandchildren. In the first session of occupational therapy, she was depressed that she could not perform her role as a homemaker, given a severe tremor. Following the philosophical assumption of occupational therapy that performing tasks clients find meaningful will increase their motivation and positive rehabilitation outcomes, the therapist decided to work on a task related to household chores. Therefore, the therapist showed her how to pare an apple controlling for a tremor, and with this guidance she did so successfully. Her eyes sparkled and she smiled, saying "I did it! I never thought I could, but I did it! I am not that worthless, am I?" After this successful experience, she became eager to try cooking using strategies to control a tremor, and to move on to more difficult tasks related to her role as a homemaker.

Figure 1 contains the example of Mrs. Sato in italic font. Self-efficacy in this example is how confident Mrs. Sato is about her ability to pare an apple despite a tremor, and outcome expectancy is her expectation of the degree to which paring an apple successfully can change her role in the family "If I could pare an apple, I would be able to cook meals for my family and fulfill my role as a homemaker, which is wonderful." In order to achieve the actual behavior, which is to pare an apple, Mrs. Sato needs not only to feel confident enough about her ability to actually pare an apple, but also to have a positive outcome expectancy about what being able to pare an apple means to her. After the therapy session, she became eager to try other tasks because she then had both high selfefficacy and positive outcome expectancy toward tasks related to her role in her family as a 
Table 1. The effects of different patterns of self-efficacy and outcome expectancies on behavior and affective states

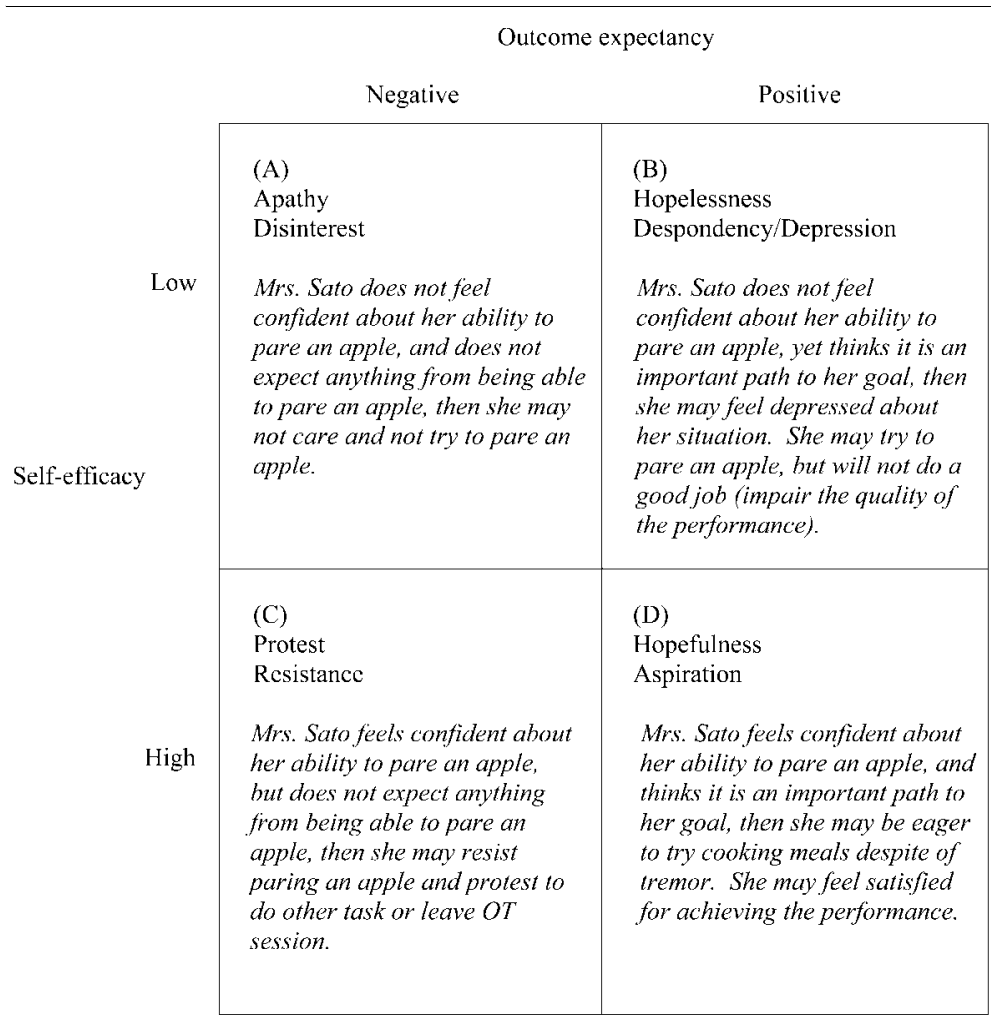

Adapted from Self-efficacy: The exercise of control (p. 20), by A. Bandura, 1997, Ncw York: W.H. Freeman and Company.

homemaker.

The interactive effects of self-efficacy and outcome expectancy

Self-efficacy and outcome expectancy work interactively to change behavior toward and emotional responses to the task. Table 1 shows the effects of different patterns of self-efficacy and outcome expectancies on behavior and affective states. Different patterns of self-efficacy and outcome expectancy are hypothesized to have different psychosocial and emotional effects. In Table 1, high self-efficacy and a positive outcome expectancy are shown as (+), and low self-efficacy and negative outcome expectancy are shown as (). The four cells show the effect of different combinations of self-efficacy and outcome expectancy.
Cell A Apathy of the table shows that if people have both low self-efficacy and negative outcome expectancy, they may become apathetic and resigned to a self-perceived unsatisfying life and not put effort into the task. For Mrs. Sato, she may believe she cannot pare an apple, and if she also does not expect anything positive from being able to pare the apple, she might feel apathetic, be disinterested to the task and not try to pare an apple.

Cell B Hopelessness of the table shows the pattern in which people perceive themselves as ineffectual but have a positive expectation of what the outcome can bring. This situation is apt to give rise to self-disparagement and depression (Bandura, 1997). For Mrs. Sato, this problem might have been what was happening to her before she had her occupational therapy session. She did 
not feel confident about her ability to pare the apple and, yet thought paring an apple was an important task, she was feeling depressed at not being able to perform the task. She may try to pare an apple, but loss of self-efficacy may impair the quality of the performance and she may not do a good job.

Cell C Protest of the table shows that if people have high self-efficacy but negative outcome expectancy, people will not do the task, since they believe they cannot gain a valued outcome. For example, if Mrs. Sato does not value the future outcome of being able to pare an apple, she would not find paring an apple as an important task for her to achieve, and she may resist paring an apple and protest to do other task or leave OT session.

Cell D Hopefulness of the table shows that high self-efficacy and positive outcome expectancy promotes productive engagement in tasks and produces satisfaction and fulfillment. As an example, Mrs. Sato, having achieved the task successfully in the occupational therapy session, she felt satisfied for achieving the task, and regained her self-efficacy about preparing food. As a result, she became eager to try paring an apple despite of tremor.

Some studies in public health (Grembowski, Patrick, Diehr, \& Durham, 1993; Schuster, Petosa, \& Petosa, 1995; Schwarzer \& Fuchs, 1995) support this idea that there is an interactive effect of self-efficacy and outcome expectancy. For example, Grembowski et al. (1993) found both self-efficacy and outcome expectancy are negatively associated with health risk behavior, and Schuster et al. (1995) found a similar effect on intentional exercise. Schwarzer et al. (1995) used a hierarchical regression analysis of self-efficacy, outcome expectancy, and vulnerability to predict intention to engage in cancer screening behavior for older females (age from 40 to 70). A significant interaction between self-efficacy and outcome expectancy was found in older females $(\beta=-19, \mathrm{p}<.01)$, suggesting that positive outcome expectancy may help to raise the intention to screen for cancer in women of lower self-efficacy.

As shown, self-efficacy and outcome expectancy are not only a factor of one's behavior by itself, but also work interactively to change behavior toward and emotional responses to the task. To understand a person's behavior and affective state and predict his or her future performance, it is important to understand both self-efficacy and outcome expectancy and their interactions.

\section{Analysis of Measurements}

This paper reviews measures specifically focused on older adults, because that group is one of the main populations of occupational therapy (Rijken \& Dekker, 1998), and a group that will show rapid growth over the next decade or two (Kinsella \& Velkoff, 2001). Some scales have already been developed specifically for selfefficacy or outcome expectancy related to rehabilitation with older adults. In this part, measurements for self-efficacy and outcome expectancy are analyzed separately.

\section{Analysis of self-efficacy measures used in older adults}

A search of the literature using PsychINFO and OVID database, with the keywords of "selfefficacy," "scale," "rehabilitation," and "older adults" retrieved 22 scales. Of the 22 retrieved scales, 17 measure task-specific self-efficacy, and five measure general self-efficacy. The taskspecific self-efficacy scales measure people's beliefs about their ability to do a specific task, such as "touch and hold the snake with gloved hand" in a specific situation, such as "during participating in a research study" (Bandura \& Adams, 1977). General self-efficacy is overall confidence in dealing with life challenges, not just confidence in doing a specific task, such as "I can always manage to solve difficult problems if I try hard enough" (Schwarzer \& Jerusalem, 1995). Five scales were found that measure this type of selfefficacy (Burger \& Cooper, 1979; Sakano \& Tohjoh, 1986; Schwarzer \& Jerusalem, 1995; Sherer \& Maddux, 1982; Tipton \& Worthington, 1984). However, Bandura (1997) cautions that general self-efficacy scales "violate the basic assumption of the multidimensionality of selfefficacy beliefs" (p. 48) and some researchers also 
Table 2. Task-specific self-efficacy scales used in older adults

\begin{tabular}{|c|c|c|c|c|c|c|c|c|c|}
\hline & \multirow[t]{3}{*}{ Instrument } & \multicolumn{7}{|c|}{ Task domains } & \multirow[t]{3}{*}{ Authors (year) } \\
\hline & & \multicolumn{3}{|c|}{ Mobility $\mathrm{S}$} & \multicolumn{2}{|c|}{ Symptom } & \multicolumn{2}{|c|}{ Exercise } & \\
\hline & & BADL & & Comm. & & Emotion & & IADL & \\
\hline 1 & Self-efficacy scale & $\mathrm{X}$ & $X$ & $\mathrm{X}$ & $\mathrm{X}$ & $\mathrm{X}$ & $\mathrm{X}$ & $X$ & Lorig et al. (1996) \\
\hline 2 & Rheumatoid Arthritis Self-efficacy (RASE) scale & e $X$ & $\mathrm{X}$ & $\mathrm{X}$ & $\mathrm{X}$ & $\mathrm{X}$ & $\mathrm{X}$ & $\mathrm{X}$ & Hewlett et al. (2001) \\
\hline 3 & Depression Coping Self-Efficacy Scale (DCSES) & $x$ & & $\mathrm{X}$ & $\mathrm{X}$ & $\mathrm{X}$ & $\mathrm{X}$ & $\mathrm{X}$ & Perraud (2000) \\
\hline 4 & Arthritis Self-efficacy scale & $\mathrm{X}$ & $\mathrm{X}$ & & $\mathrm{X}$ & $\mathrm{X}$ & & & Lorig et al. (1989) \\
\hline 5 & Self-Efficacy Gauge & $\mathrm{X}$ & $\mathrm{X}$ & $\mathrm{X}$ & & & & $\mathrm{X}$ & Gage et al. (1994b) \\
\hline 6 & Self-Efficacy for Participation in & & & & & & & & \\
\hline & Rehabilitation Scale & $\mathrm{X}$ & $\mathrm{X}$ & & & & & & Resnick (1998) \\
\hline 7 & Self-Efficacy Measures & & & $\mathrm{X}$ & $\mathrm{X}$ & $\mathrm{X}$ & $\mathrm{X}$ & & Fry et al. (2001) \\
\hline 8 & Health care self-efficacy scale (KI-SE) & & & $\mathrm{X}$ & $\mathrm{X}$ & & & & Krantz et al. (1980) \\
\hline 9 & Self-efficacy scale & & & & $\mathrm{X}$ & $\mathrm{X}$ & & & Montgomery et al. (1994) \\
\hline 10 & Health care self-efficacy scale (HSE) & & & & $\mathrm{X}$ & $\mathrm{X}$ & & & Smith et al. (1984) \\
\hline 11 & Self-Efficacy in Leisure-time physical activity sce & cale & & & & & $\mathrm{X}$ & $\mathrm{X}$ & Stevens et al. (2001) \\
\hline 12 & The Fall Efficacy Scale & $\mathrm{X}$ & & & & & & & Tinetti et al. (1990) \\
\hline 13 & Physical Self-Efficacy (PSE) Scale & & $\mathrm{X}$ & & & & & & Ryckman et al. (1982) \\
\hline 14 & Occupational Self-Efficacy Index (OSEI) & & & & & & & $\mathrm{X}$ & Fletcher et al. (1992) \\
\hline 15 & Self-efficacy scale & & & & & & $\mathrm{X}$ & & Moore (1992) \\
\hline 16 & Self-Efficacy for Functional Ability Scale & & & & & & $\mathrm{X}$ & & Resnick (1999) \\
\hline 17 & Self-Efficacy for Exercise scale (SEE) & & & & & & $\mathrm{X}$ & & Resnick et al. (2000) \\
\hline
\end{tabular}

$\mathrm{BADL}=$ basic activities of daily living, Comm. $=$ communication, Emotion=emotional well being, IADL=instrumental activities of daily living

have shown the limitation of general self-efficacy scales (Tipton \& Worthington, 1984; Wang \& Richarde, 1988). Therefore, this review focused only on the task-specific self-efficacy and its scales.

Table 2 shows the details of the 17 taskspecific self-efficacy scales. All scales were found to have a similar structure: items ask "how confident are you to do (target task)?" using a Likert scale, which is the format Bandura and Adams (1977) used in their original study. Only one scale (Gage et al., 1994) out of the 17 scales was used in occupational therapy research. The only difference across these 17 scales was the uniqueness of target tasks; each scale had a different target task and age group. However, they did not all precisely follow the theoretical framework of Bandura. Bandura and Adams (1977) postulated three parameters of selfefficacy; magnitude, strength and generality. "Magnitude" refers to the level of difficulty of the task that is rated from easy to difficult, "strength" refers to the degree to which people believe they can succeed at a given level of task difficulty (magnitude), and "generality" of self-efficacy refers to the degree to which the person's selfefficacy for one task transfers to other similar or different tasks. By measuring all three parameters, an investigator would be able to predict the participants' future performance. Unfortunately, all of the 17 scales were found to be only measuring the level of self-efficacy parameter (strength), and did not include magnitude or generality. If a scale is not validly following the theoretical framework, using that scale can result in a misunderstanding of the phenomenon.

\section{Analysis of outcome expectancy measures used in older adults}

A search of the literature using PsychINFO and OVID and the keyword of "outcome expectancy," "scale," "rehabilitation," and "older adults" retrieved only two outcome expectancy scales related to Bandura's self-regulation theory, both from the same study conducted in the field of nursing research. Resnick (1998) developed two self-efficacy scales and two outcome expectancy scales in her study of patient education for older 
adults. Her Outcome Expectation for Functional Ability (OEFA) scale had six items, such as "How strongly do you believe that doing your own bathing and dressing, rather than having others do it for you, will improve your strength and ability?" The Outcome Expectation for Participation in Rehabilitation (OEPR) scale had three items, such as "How confident are you that participating in 3 hours of therapy a day will help you increase your ability to take care of yourself?" Each item is rated on a 5-point Likert scale ranging from 1 (not at all) to 5 (a great deal).

However, the terminology Resnick used in the OEFA may have biased the answers. She implied the research hypothesis in the phrasing of the item, such as "How strongly do you believe that doing your own bathing and dressing, rather than having others do it for you, will improve your strength and ability?" This phrase could imply the hypothesis that "doing your own bathing and dressing, rather than having others do it for you, will improve your strength and ability." Asking clients how much they agree with this sentence is a leading question. Rosenthal and Rosnow (1991) caution the artifacts that may result when demand of the researcher is too clear. Rosenthal and Rosnow and other studies in social psychology (Brehm, 1966; Wicklund, 1974) have found that, when demand characteristics are too clear, a person typically attempts to acquiesce to the demand, although some attempt to do the opposite of what is demanded. It is important to make sure that participants are blind to the hypothesis. Moreover, the outcome one expects from doing the task (outcome expectancy) may vary with each individual. As Resnick's items explicitly state a specific outcome expectation, she does not allow participants to express their unique expectancies related to doing the task.

\section{Analysis of studies focused on the interaction of self-efficacy and outcome expectancy in older adults}

Resnick (1998) used these two outcome expectancy scales reviewed in the last section and other two task-specific self-efficacy scales to examine the impact of self-efficacy and outcome expectations on older adults in a rehabilitation program. She found that, based on an exploratory regression analysis, OEFA at baseline was shown to be an important contribution $\left(\mathrm{R}^{2}\right.$ change $=.06$, $\mathrm{p}<.05)$ to the prediction of the variance in the older adults' level of functioning after rehabilitation.

However, Resnick's study did not address the interaction between self-efficacy and outcome expectancy. Similar to this study, other studies in public health (Grembowski et al., 1993; Schuster et al., 1995) also have examined both outcome expectancy and self-efficacy, but examined them separately, looking at whether each affects and predicts behavior. In Bandurå̊fs self-regulatory system, self-efficacy and outcome expectancy affect task performance interactively (see Table 1). The interaction between self-efficacy and outcome expectancy may have affected the results, and not examining the interaction could yield only a partial understanding of motivation and behavior. Given the lack of available instruments, new measurement tools are needed that can measure both self-efficacy and outcome expectancy and their interactions.

\section{Self-efficacy and Outcome Expectancy in a Clinical Context}

In this section, the discussion is about how theory and measures in this area have been applied to a clinical context in occupational therapy. In a clinical context, the interaction of self-efficacy and outcome expectancy is rarely and possibly never evaluated, even though many scales have been developed specifically to measure self-efficacy. In the clinical reasoning process, a therapist automatically evaluates a client's motivation without using scales. A therapist observes clients' non-verbal and verbal behavior to identify their experience as related to the four conditions of Table 1. This evaluation process is called "conditional reasoning" (Fleming, 1994).

As an example, this conditional reasoning process can be applied to the occupational therapy session of Mrs. Sato. From the interaction with Mrs. Sato, the therapist understood that Mrs. Sato felt depressed (the motivational state of Hopelessness in Table 1), based on her affect and her statement that she could not perform her 
important and meaningful roles of homemaker. Likewise, watching the sparkle in Mrs. Sato's eyes with her smile and positive comments after she succeeded in paring the apple, the therapist sensed that her level of self-efficacy increased and that she was ready to move on to more difficult tasks (the motivational state of Hopefulness in Table 1). By tying behavior to Mrs. Sato $\AA$ fs possible affect, the therapist could understand that she has positive outcome expectancy for the household task and that she has low or high self-efficacy on that task.

Recent studies in occupational therapy support that this conditional reasoning is a reliable way to understand the client's affect and motivation (DeGroat, Lyons, \& Tickle-Degnen, 2006; Lyons, Tickle-Degnen, Henry, \& Cohn, 2004; Lyons, Tickle-Degnen, \& DeGroat, 2005; Tickle-Degnen \& Lyons, 2004). Lyons and colleagues (2004) found an association between the judged personality by therapists during a clinical interview and the clients' self-described personality and mood. This finding supported the idea that therapists can accurately pinpoint a client's affect and motivation through both verbal and nonverbal behavior during open-ended clinical interviews.

Moreover, using an open-ended qualitative questioning process, rather than structured and standardized scales, promotes a natural flow of intervention. Take Mrs. Sato as an example. It may interrupt Mrs. Sato's occupational performance if a therapist keeps asking her to score her level of self-efficacy on a Likert scale each time she performs a task. Also, since an occupational therapy session usually lasts 20 to 30 minutes, there is not enough time to sit down and fill out scales every time. In a limited time frame like that involved in a clinic intervention, it may not be very beneficial to use a structured scale.

In addition, conditional reasoning also helps the therapist to respond in a way that will develop a strong working alliance with the client (Cox, Holbrook, \& Rutter, 1981; Cox, Rutter, \& Holbrook, 1981; Cruz \& Pincus, 2002; Eisenthal, Koopman, \& Lazare, 1983; Lustig, Strauser, Rice, \& Rucker, 2002; Roter \& Hall, 1992; Safran \& Muran, 1998). Working alliance is defined as collaboration between a client and a counselor based on the development of an attachment bond (Bordin, 1979). The development of strong working alliance is found to result in better outcomes for a variety of rehabilitation interventions (Al-Darmaki \& Kivlighan, 1993; Connors, Carroll, DiClemente, Longabaugh, \& Donovan, 1997; Cruz \& Pincus, 2002; Goering, Wasylenki, Lindsay, Lemire, \& Rhodes, 1997; Kivlighan \& Shaughnessy, 2000; Kokitovic \& Tracy, 1990; Mallinckrodt \& Nelson, 1991). Although no studies on working alliance have been done in occupational therapy area which may limit the implication in other disciplines, here again, using an unstructured interaction is likely to be more flexible way to assess a client in a clinical setting than use of a paper-and-pencil rating scale.

\section{Implications for Practice}

The self-regulatory system model explains the interactive effect of self-efficacy and outcome expectancy on behavior (Bandura, 1977, 1986, 1991, 1997), and this model is highly consistent with philosophical assumptions in occupational therapy practice. However, Bandura's selfregulatory model has not yet been integrated systematically into occupational therapy clinical practice (Gage, Noh, Polatajko, \& Kaspar, 1994), and the importance of outcome expectancy has not been recognized in the occupational therapy literature. This lack of integration of the model into practice may be due to occupational therapists' lack of awareness of the constructs of self-efficacy and outcome expectancy, and to the lack of useful assessment tools for measuring these constructs (Gage et al., 1994).

In clinical settings, therapists often make judgments about clients' motivational state quickly and spontaneously throughout clinical interaction. However, the process of this identification is so automatic that it is not wellarticulated and is thought to be "art." Clear understanding of self-efficacy and outcome expectancy is important because those are the factors influencing the actual task performance. The studies reviewed showed that current methods of assessing the client's motivational states involve self-report measures which do not enable 
therapists to quickly and spontaneously make their judgment. By observing a client's behavior and affective states during an open-ended clinical interview, therapists may be able to identify rapidly whether the person has positive or negative outcome expectancies and high or low selfefficacy, and quickly adjust their intervention to be more effective. For example, for a client who is apathetic or protesting, the therapist can change the activity to increase the client's positive outcome expectancy. If the client was resisting paring an apple, it might be better to change the activity to which the client finds it meaningful such as ironing a shirt. Likewise, for a client who is hopeless, the therapist can help the client to increase self-efficacy on that activity. If the client could not pare an apple easily, the therapist would demonstrate strategies such as stabilizing the apple and using an adaptive equipment to perform the activity successfully therefore increase the client's self-efficacy. Though a limitation of using the self-regulatory system model could be that there may be other factors affecting people's behaviors such as physical dysfunction or pain, conditional reasoning can be used to understand the factors why the client is in a specific motivational state and adjust the intervention accordingly.

Research is currently underway to develop a systematic method for identification of what client cues are valid and reliable expressions of selfefficacy and outcome expectancy. Once we are able to measure these expressions reliability and validly, we may be able to improve the intervention to specifically address each motivational state.

Acknowledgment: The author thanks Dr. Linda Tickle-Degnen, Ph.D., OTR/L, FAOTA, Dr. Patricia Nemec, Psy.D., C.R.C., C.P.R.P. and Dr. Nancy K. Latham, PhD., PT for their comments on earlier drafts of this paper. This paper was completed in partial fulfillment of the requirements for the author's doctoral degree in rehabilitation sciences.

\section{References}

Al-Darmaki, F., \& Kivlighan, D. M. (1993).
Congruence in client-counselor expectations for relationship and the working alliance. Journal of Counseling Psychology, 40, 379-384.

Bakshi, R., Bhambhani, Y., \& Madill, H. (1991). The effects of task preference on performance during purposeful and nonpurposeful activities. Am. J. Occup. Ther., 45, 912-916.

Bandura, A. (1977). Self-efficacy: Toward a unifying theory of behavioral change. Psychological Review, 84, 191-215.

Bandura, A. (1986). Social foundations of thought and action: A social cognitive theory. Upper Saddle River, NJ: Prentice-Hall.

Bandura, A. (1991). Social cognitive theory of selfregulation. Organizational Behavior and Human Decision Processes, 50, 248-287.

Bandura, A. (1995). Self-efficacy in changing societies. New York: Campridge University Press.

Bandura, A. (1997). Self-efficacy: The exercise of control. New York: W.H. Freeman.

Bandura, A., \& Adams, N. E. (1977). Analysis of self-efficacy theory of behavioral change. Cognitive Therapy and Research, 1, 287-310.

Bordin, E. S. (1979). The generalizability of the psychoanalytic concept of the working alliance. Psychotherapy: Theory, Research \& Practice, 16, 252-260.

Brehm, J. (1966). A theory of psychological reactance. New York: Macmillan.

Burger, J. M., \& Cooper, H. M. (1979). The desirability of control. Motivation and Emotion, 3, 381-393.

Christiansen, C. (1991). Occupational therapy: Intervention for life performance. In C. Christiansen \& C. Baum (Eds.), Occupational therapy: Overcoming human performance deficits (pp. 3-43). Thorofare, NJ: SLACK.

Connors, G. J., Carroll, K. M., DiClemente, C. C., Longabaugh, R., \& Donovan, D. M. (1997). The therapeutic alliance and its relationship to alcoholism treatment participation and outcome. Journal of Consulting and Clinical Psychology, 65, 588-598.

Cox, A. C., Holbrook, D., \& Rutter, M. (1981). Psychiatric interviewing techniques: VI. Experimental study: Eliciting feelings. British Journal of Psychiatry, 139, 144-152.

Cox, A., Rutter, M., \& Holbrook, D. (1981). Psychiatric interviewing techniques: V. Experimental study: Eliciting factual information. British Journal of Psychiatry, 139, 29-37.

Cruz, M., \& Pincus, H. A. (2002). Research on the 
influence that communication in psychiatric encounters has on treatment. Psychiatric Services, 53, 1253-1265.

DeGroat, E. J., Lyons, K. D., \& Tickle-Degnen, L. (2006). Favorite activity interview as a window into the identity of people with Parkinson's disease. OTJR: Occupation, Participation and Health, 26, 56-68.

Dickerson, A. E., \& Fisher, A. G. (1997). Effects of familiarity of task and choice on the functional performance of younger and older adults. Psychology and Aging, 12, 247-254.

Eisenthal, S., Koopman, C., \& Lazare, A. (1983). Process analysis of two dimensions of the negotiated approach in relation to satisfaction in the initial interview. Journal of Nervous and Mental Disease, 171, 49-54.

Ferguson, J. M., \& Trombly, C. A. (1997). The effect of added-purpose and meaningful occupation on motor learning. Am. J. Occup. Ther., 51, 508-515.

Fleming, M. H. (1994). Conditional reasoning: Creating meaningful experiences. In C. Mattingly \& M. H. Fleming (Eds.), Clinical reasoning: Forms of inquiry in a therapeutic practice (pp. 197-235). Philadelphia: F.A. Davis.

Fletcher, W. L., Hansson, R. O., \& Bailey, L. (1992). Assessing occupational self-efficacy among middle-aged and older adults. Journal of Applied Gerontology, 11, 489-501.

Fry, P. S. (2001). Predictors of health-related quality of life perspectives, self-esteem, and life satisfactions of older adults following spousal loss: An 18-month follow-up study of widows and widowers. Gerontologist, 41, 787-798.

Gage, M., \& Polatajko, H. (1994). Enhancing occupational performance through an understanding of perceived self-efficacy. Am. J. Occup. Ther., 48, 452-461.

Gage, M., Noh, S., Polatajko, H. J., \& Kaspar, V. (1994). Measuring perceived self-efficacy in occupational therapy. Am. J. Occup. Ther., 48, 783-790.

Goering, P., Wasylenki, D., Lindsay, S., Lemire, D., $\&$ Rhodes, A. (1997). Process and outcome in a hostel outreach program for homeless clients with severe mental illness. American Journal of Orthopsychiatry, 67, 607-617.

Grembowski, D., Patrick, D., Diehr, P., \& Durham, M. (1993). Self-efficacy and health behavior among older adults. Journal of Health and Social Behavior, 34, 89-104.

Hewlett, S., Cockshott, Z., Kirwan, J., Barrett, J.,
Stamp, J., \& Haslock, I. (2001). Development and validation of a self-efficacy scale for use in British patients with rheumatoid arthritis (RASE). Rheumatology, 40, 1221-1230.

Kinsella, K., \& Velkoff, V.A. (2001). An aging world: 2001. Washington, DC: U.S. Government Printing Office.

Kircher, M. A. (1984). Motivation as a factor of perceived exertion in purposeful versus nonpurposeful activity. Am. J. Occup. Ther., 38, 165-170.

Kivlighan, D. M. J., \& Shaughnessy, P. (2000). Patterns of working alliance development: A typology of client's working alliance ratings. Journal of Counseling Psychology, 47, 362-371.

Kokitovic, A., \& Tracy, T. (1990). Working alliance in the early phase of counseling. Journal of Counseling Psychology, 37, 16-21.

Krantz, D. S., Baum, A., \& Wideman, M. V. (1980). Assessment of preferences for self-treatment and information in health care. Journal of Personality and Social Psychology, 39, 977-990.

Lorig, K., Chastain, R. L., Ung, E., Shoor, S., \& Holman, H. (1989). Development and evaluation of a scale to measure perceived self-efficacy in people with arthritis. Arthritis and Rheumatism, 32, 37-44.

Lorig, K., Stewart, A. L., Ritter, P., Gonzalez, V., Laurent, D. D., \& Lynch, J. (1996). Outcome measures for health education and other health care interventions. Thousand Oaks, CA: Sage Publications.

Lorig, K. R., Ritter, P., Stewart, A. L., Sobel, D. S., Brown, B. W., Jr., Bandura, A., et al. (2001). Chronic disease self-management program: 2-year health status and health care utilization outcomes. Medical Care, 39, 1217-1223.

Low, M. (2002). Assessing roles and competence. In C. A. Trombly \& M. V. Radomski (Eds.), Occupational therapy for physical dysfunction (5th ed., pp. 31-45). Philadelphia: Lippincott Williams \& Wilkins.

Lustig, D. C., Strauser, D. R., Rice, N. D., \& Rucker, T. F. (2002). The relationship between working alliance and rehabilitation outcomes. Rehabilitation Counseling Bulletin, 46, 24-32.

Lyons, K. D., Tickle-Degnen, L., Henry, A., \& Cohn, E. (2004). Impressions of personality in Parkinson's Disease: Can rehabilitation practitioners see beyond the symptoms? Rehabilitation Psychology, 49, 328-333.

Lyons, K. D., Tickle-Degnen, L., \& DeGroat, E. J. 
(2005). Inferring personality traits of clients with Parkinson's disease from their descriptions of favourite activities. Clinical Rehabilitation, 19, 799-809.

Mallinckrodt, B., \& Nelson, M. L. (1991). Counselor training level and the formation of the psychotherapeutic working alliance. Journal of Counseling Psychology, 38, 133-138.

McAuley, E. (1993). Self-efficacy, physical activity, and aging. In J. R. Kelly (Ed.), Activity and aging: Staying involved in later life (pp. 187-205) Thousand Oaks, CA: Sage.

Meyer, A. (1922). The philosophy of occupational therapy. Archives of Occupational Therapy, 1, 110.

Miller, L., \& Nelson, D. L. (1987). Dual-purpose activity versus single-purpose activity in terms of duration on task, exertion level, and affect. Occupational Therapy in Mental Health, 7, 5567.

Montgomery, E. B., Jr., Lieberman, A., Singh, G., \& Fries, J. F. (1994). Patient education and health promotion can be effective in Parkinson's disease: A randomized controlled trial. PROPATH Advisory Board. American Journal of Medicine, 97, 429-435.

Moore, E. J. (1992). The relationship among selfefficacy, health knowledge, self-rated health status, and selected demographics as determinants of health promoting behavior in older adults (Doctoral dissertation, University of Akron, 1992). Dissertation Abstracts International, 53, 1788.

Morton, G. G., Barnett, D. W., \& Hale, L. S. (1992). A comparison of performance measures of an added-purpose task versus a single-purpose task for upper extremities. Am. J. Occup. Ther., 46, 128-133.

Murphy, S., Trombly, C., Tickle-Degnen, L., \& Jacobs, K. (1999). The effect of keeping an endproduct on intrinsic motivation. Am. J. Occup. Ther., 53, 153-158.

Nakamura, H. (1995). Overuse and misuse in occupational therapy (in Japanese). The Japanese Journal of Occupational Therapy, 29, 336-337.

Oka, S. (1995). Overuse and misuse in psychiatry (in Japanese). The Japanese Journal of Occupational Therapy, 29, 346.

Okumura, N. (2003). Experimental study of overuse in treatment plan for changing the dominant hand (in Japanese). Kitasato University Journal of Occupational Therapy, 6, 101-103.
Perraud, S. (2000). Development of the Depression Coping Self-Efficacy Scale (DCSES). Archives of Psychiatric Nursing, 14, 276-284.

Prochaska, J. O., DiClemente, C. C., \& Norcross, J. C. (1992). In search of how people change: Applications to addictive behaviors. American Psychologist, 47, 1102-1114.

Resnick, B. (1998). Efficacy beliefs in geriatric rehabilitation. Journal of Gerontological Nursing, 24, 34-44.

Resnick, B. (1999). Reliability and validity testing of the self-efficacy for functional activities scale. Journal of Nursing Measurement, 7, 5-20.

Resnick, B., \& Jenkins, L. S. (2000). Testing the reliability and validity of the Self-Efficacy for Exercise scale. Nursing Research, 49, 154-159.

Riccio, C. M., Nelson, D. L., \& Bush, M. A. (1990). Adding purpose to the repetitive exercise of elderly women through imagery. Am. J. Occup. Ther., 44, 714-719.

Rijken, P. M., \& Dekker, J. (1998). Clinical experience of rehabilitation therapists with chronic diseases: A quantitative approach. Clinical Rehabilitation, 12, 143-150.

Rosenthal, R., \& Rosnow, R. L. (1991). Essentials of behavioral research: Methods and data analysis (2 ed.). Boston: McGraw-Hill.

Roter, D. L., \& Hall, J. A. (1992). Doctors talking with patients/patients talking with doctors: Improving communication in medical visits. Westport, CT: Auburn House.

Ryckman, R. M., Robbins, M. A., Thornton, B., \& Cantrell, P. (1982). Development and validation of a physical self-efficacy scale. Journal of Personality and Social Psychology, 42, 891-900.

Safran, J. D., \& Muran, J. C. (1998). The therapeutic alliance in brief psychotherapy: General principles. In J. D. Safran \& J. C. Muran (Eds.), The therapeutic alliance in brief psychotherapy. (pp. 217-229). Washington DC: American Psychological Association.

Sakano, Y., \& Tohjoh, M. (1986). The General Selfefficacy Scale (GSES): Scale development and validation (in Japanese). Japanese Journal of Behavior Therapy, 12, 73-82.

Schuster, C., Petosa, R., \& Petosa, S. (1995). Using social cognitive theory to predict intentional exercise in post-retirement adults. Journal of Health Education, 26, 14-21.

Schwarzer, R., \& Fuchs, R. (1995). Changing risk behaviors and adopting health behavior: A role of self-efficacy beliefs. In A. Bandura (Ed.), Self- 
efficacy in changing societies (pp. 259-287). New York: Cambridge University Press.

Schwarzer, R., \& Jerusalem, M. (1995). Generalized Self-efficacy Scale. In S. Weinman, S. Wright, \& M. Jonhston (Eds.), Measures in health psychology: A user's portfolio. Causal and control beliefs (pp. 35-37). Windsor, UK: nferNelson.

Sherer, M., \& Maddux, J. E. (1982). The SelfEfficacy Scale: Construction and validation. Psychological Reports, 51, 663-671.

Smith, R. A. (1984). Measuring desire for control of health care processes. Journal of Personality and Social Psychology, 47, 415-426.

Stevens, M., Bakker-van Dijk, A., de Greef, M. H. G., Lemmink, K. A. P. M., \& Rispens, P. (2001). A Dutch translation of a questionnaire assessing self-efficacy in leisure-time physical activity. Journal of Aging and Physical Activity, 9, 223232.

Takahashi, K. (2002). Effects of added-purpose activities on mental concentration assessed by subjective time estimation and incidence of Fm $\theta$ wave (in Japanese). Kitasato University Journal of Occupational Therapy, 5, 156-169.

Thibodeaux, C. S., \& Ludwig, F. M. (1988). Intrinsic motivation in product-oriented and non-productoriented activities. Am. J. Occup. Ther., 42, 169175.

Tickle-Degnen, L., \& Lyons, K. D. (2004). Practitioners' impressions of patients with
Parkinson's disease: The social ecology of the expressive mask. Social Science \& Medicine, 58, 603-614.

Tinetti, M. E., Richman, D., \& Powell, L. (1990). Falls efficacy as a measure of fear of falling. Journals of Gerontology, 45, 239-243.

Tipton, R. M., \& Worthington, E. L. (1984). The measurement of generalized self-efficacy: A study of construct validity. Journal of Personality Assessment, 48, 545-548.

Trombly, C. (1993). Anticipating the future: Assessment of occupational function. Am. J. Occup. Ther., 47, 253-257.

Trombly, C. (1995). Occupation: Purposefulness and meaningfulness as therapeutic mechanisms. Am. J. Occup. Ther., 49, 960-972.

Trombly, C. (2002). Occupation. In C. Trombly \& M. V. Radomski (Eds.), Occupational therapy for physical dysfunction (4th ed., pp. 255-281). Philadelphia: Lippincott Williams \& Wilkins.

Wang, A. Y., \& Richarde, R. S. (1988). Global versus task-specific measures of self-efficacy. Psychological Record, 38, 533-541.

White, R. W. (1971). The urge towards competence. Am. J. Occup. Ther., 25, 271-280.

Wicklund, R. A. (1974). Freedom and reactance. Potomac, MD: Erlbaum.

Yoder, R. M., Nelson, D. L., \& Smith, D. A. (1989). Added-purpose versus rote exercise in female nursing home residents. Am. J. Occup. Ther., 43, 581-586. 